WSRC-TR-92-031

\title{
LIMITS FOR THE NEW DWPF MELTER OFF-GAS JUMPER I. D. (U)
}

\author{
WSRC-TR- $-92-0.31$
}

by A. S. Choi

DE93 009112

Westinghouse Savannah River Company

Savannah River Site

Aiken, South Carolina 29808

Other Authors:

This paper was prepared in connection with work done under Contract No. DE-AC09-89SR18035 with the U. S. Department of Energy. By acceptance of this paper, the publisher and/or recipient acknowledges the U. S. Government's right to retain a nonexclusive, royaliy-free license in and to any copyright covering this paper, along with the right to reproduce and to authorize others to reproduce all or part of the copyrighted paper.

\section{MASTER}




\section{DISCLAIMER}

This report was prepared as an account of work sponsored by an agency of the United States Government. Neither the United States Government nor any agency thereof, nor any of their employees, makes any warranty, express or implied, or assumes any legal liability or responsibility for the accuracy, completeness, or usefulness of any information, apparatus, product, or process disclosed, or represents that its use would not infringe privately owned rights. Reference herein to any specific commercial product, process, or service by trade name, trademark, manufacturer, or otherwise does not necessarily constitute or imply its endorsement, recommendation, or favoring by the United States Government or any agency thereof. The views and opinions of authors expressed herein do not necessarily state or reflect those of the United States Government or any agency thereof.

This report has been reproduced directly from the best available copy.

Available to DOE and DOE contractors from the Office of Scientific and Technical Information, P. O. Box 62, Oak Ridge, TN 37831; prices available from (615) $576-8401$.

Available to the public from the National Technical Information Service, U. S. Department of Commerce, 5285 Port Royal Rd., Springfield, VA 22161. 
Keywords: DWPF, Melter OffGas Jumper, I.D.

January 22, 1992

MEMORANDUM

To: C. T. Randall, 704-T

From: A. S. Choi, 704-1T BAC

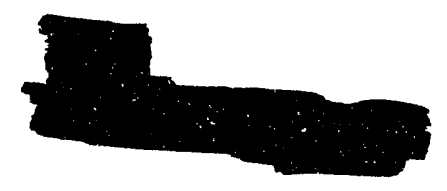

LMMTSS FOR THE NEW DWPE MELTER OFT-GAS JUMPER I.D. (U)

\section{Introduction and Summary}

In order to minimize solids deposition in the off-gas line between the primary film cooler and the quencher, SRL recommended earlier that a now DWPF melter off-gas jumper be built which would increase the off-gas velocity from less than $40 \mathrm{ft} / \mathrm{s}$ under the original design to at least $55 \mathrm{ft} / \mathrm{s}$, excluding the melter air inleakage. Two design changes proposed for the new jumper were: (1) relocation of the entry point for the melter pressure control air from the current position near the quencher to near the film cooler exit, and (2) reduction of the inside diameter of the jumper from 8.33 to 7.156 inches.

The objective of this study was to confirm the optimum I.D. proposed earlier and determine the upper and lower limits for the optimum I.D. to initiate the actual design process. Based on more conservative bases for cptimization used in this study, it was determined that the design limits for the new jumper I.D. is $7.15 \leq$ I.D. 57.25 inches. 


\section{Bases for Dotimization}

Determination of the optimum diameter for the new jumper resulted in a new set of operating conditions for the melter off-gas system.' These revised operating conditions were the product of an extensive cross-checking to determine if all the key design conditions that are shown in Table 1 were met under those conditions. Conditions \#5 and $\# 8$ included additional conservatism over those considered in an earlier study, 1 while Condition $\# 6$ was added for the first time in this study.

TABLE_ Conditions for Design and Optimization

No. Condition Value To avoid possibility of

1. Actual/stoichiometric $\mathrm{O}_{2}$ ratio $\geq 1.5$ at $3 \mathrm{X}$ nominal combustible feed

2. Plenum gas residence time $28 \mathrm{sec}$ at nominal (1X) off-gas now

3. Film cooler air/steam (mass)

4. Film cooling effectiveness

5. Off-gas temperature at the film cooler exit

6. Off-gas velocity at the film cooler exit

7. Off-gas velocity including pressure control air flow

8. Off-gas LE, a OOCT at $3 \mathrm{X}$ nominal off-gas flow

9. Inlet vapor flow to SAS \#1

10. Vapor exiting SAS

11. Cooling duty @ OGCT

12. Vapor to exhauster

13. Melter pressure @ $7 X$ surge relative 10 cell
23

20.68

$<400^{\circ} \mathrm{C}$

$>50 \mathrm{sul}$

$253 \mathrm{f} / \mathrm{s}$

$<60 \%$

< 1,807 lbshr

$<2,000 \mathrm{lb} / \mathrm{hr}$

$<740 \mathrm{mPcu} / \mathrm{hr}$

$<2.062$ lba/he

$<-0.5^{n}: \mathrm{H}_{2} \mathrm{O}$
$\mathrm{O}_{2}$ depletion in plenum

poor gas mixing

steam condensation

entrance plugging

glene softening

dowastream plugging

dowastream plugging

off-gas explosion

exceeding $80 \%$ design

entrainment (90\%)

exceeding 90\% design

exceeding 90\% design

glass spill (nonpour)

\& blowing the seal pot 


\section{Process of Ontimixation}

Optimization of the new jumper I.D. and its design limits proceeded as follows:

(1) Find the largest jumper I.D. and the optimum operating conditions that satisfy all the design conditions shown in Table 1, and produce the lowest liquid waste recycle rate.

(2) Under the operating conditions determined in (1), find the smallest jumper 1.D. that still results in dynamic stability at $7 \mathrm{X}$ off-gas surge (Condition \#13).

(3) The optimum diameter is then set at the midpoint between the largest and the smallest diameters found above.

The actual steps followed in this optimization study are given next. The majority of the efforts were essentially devoted to oxamining each of the design conditions given in Table 1 in order to determine the operating windows for several key operating parameters.

\section{Step 1. Determination of Operating Wladows}

\section{Condition \#1: Actual/stoichiometric $O_{2}$ ratio 21.5 at $3 \mathrm{X}$ nominal combustlbles reed rate}

This condition ensures that oxygen will not bo depleted in the melter plenum even for the worst case of $70 \%$ aromatic carbon removal and 3 times the nominal formic acid addition during the feed preparation steps. This condition also sets the minimum air purge requirement into the plenum at $430 \mathrm{lb} / \mathrm{hr}$, including the backup film cooler purge at $350 \mathrm{lb} / \mathrm{hr}$ and the TV camera and seal pot purges at $80 \mathrm{lb} / \mathrm{hr}$ total. The air inleakage into the melter was not included in this calculation.

Condition \#2: Plenum gas residence time $\geq 8$ sec at nominal (1X) off-gas now

At a nominal slurry feed rate and the minimum air purge rate into the plenum, the highest plenum temperature that satisfies this gas residence time requirement is $900{ }^{\circ} \mathrm{C}$, measured in the thermowell. Note that the thermowell temperatures are higher than the actual gas temperatures due to radiation effects on the thermowell wall. 
According to the calculations based on the Scale Glass Melter (SGM) data, the correlation between the two temperatures is as follows:

$$
\mathrm{T}_{\text {gas }}=0.91685 \mathrm{~T}_{\mathrm{tw}}-128, \quad \text { in }{ }^{\circ} \mathrm{C}
$$

The air inleakage into the melter at the design rate of $100 \mathrm{lb} / \mathrm{hr}$ was included in the residence time calculations.

\section{Condition \#3: Fllm cooler air/steam mass ratio $\geq 3$}

At air-to-steam ratios of 2 or lower, the air, essentially at ambient temperature, can at times partially condense the steam exiting the cooling slots. 3 This can possibly lead to increased buildup of solids deposits in the film cooler. Condition \#3 eliminates any possibility of steam condensation. During the initial stages of the optimization process, the air-to-steam mass ratio was set at 3 .

\section{Condition \#4: Film cooling effectiveness $\geq 0.68$}

The definition of film cooling effectiveness was given earlier. ${ }^{1}$ This condition sets the minimum coolant flow to the film cooler required to maintain the adibatic film cooler wall temperature well below the glass softening point at the highest off-gas temperature of $\sim 700{ }^{\circ} \mathrm{C}$. This minimum coolant flow was calculated earlier to be $125 \mathrm{lb} / \mathrm{hr}$ at the air-to-steam mass ratio of 3 .

\section{Condition \#5: Off-gas temperature $\leq 400{ }^{\circ} \mathrm{C}$ at the film cooler exit}

In the new jumper, the entry puint for the molter pressure control air will be located as closely to the film cooler exit as practical. This condition ensures that the off-gas is cooled to below $4000 \mathrm{C}$, before the pressure control air is introduced. Obviously, the intention is to protect the off-gas equipment from pluggages and further meet the quencher design limit in the event of the pressure control air loss. This condition was made more conservative than the previous one which included the pressure control air in the calculation of cooled off-gas temperatures.

Furthermore, this condition lowers the highest plenum temperature allowable, set earlier by Condition $\# 2$, to $848^{\circ} \mathrm{C}$. Above $848{ }^{\circ} \mathrm{C}$, the off-gas temperature at the film cooler exit is still higher than $400^{\circ} \mathrm{C}$, even using the maximum design film cooler air and steam flows of 
583 and $245 \mathrm{lb} / \mathrm{hr}$, respectively. This condition further ensures that the region between the film cooler and the control air entry point is kept relatively deposit-free, no matter how narrow this region may be. The air inleakage into the melter was included at the design rate of $100 \mathrm{lb} / \mathrm{hr}$.

\section{Condition \#6: Off.gas velocity $\geq 50 \mathrm{ft} / \mathrm{sec}$ at the film cooler exit}

At a given plenum temperature below $848^{\circ} \mathrm{C}$, the maximum off-gas jumper I.D. was calculated by adding appropriate amounts of the film cooler air and steam to the nominal melier off-gas flow so the off-gas temperature at the film cooler exit was at the design maximum of $400{ }^{\circ} \mathrm{C}$. With the melter off-gas flow and plenum temperature both fixed, the allowable jumper I.D. is largest when the least amounts of film cooler air and steam are added. The melter air inleakage is not included in any velocity calculations. The off-gas velocity is then at least $50 \mathrm{ft} / \mathrm{sec}$ even in the absence of the pressure control air.

Condition \#7: Off-gas velocity $\geq 55 \mathrm{n} / \mathrm{sec}$ including melter pressure control air

The off-gas velocity of $55 \mathrm{ft} / \mathrm{sec}$ is the minimum velocity required to minimize the formation of solid deposits in the off-gas jumper. The minimum pressure control air was then set by this condition. As in an earlier study, 1 howover, the melter pressure control air was set at $550 \mathrm{lb} / \mathrm{hr}$ or $72 \%$ of the design capacity of the control air valve for a greater control capability of surges. It tums out that this value was more than enough to boost the off-gas velocity from 50 to $55 \mathrm{ft} / \mathrm{sec}$.

\section{Condition \#b: Noncondensable off-gas < 60\% of the LEL at $3 \mathrm{X}$ nominal off-gas now}

Both the gas temperature and the gas residence timo in the plenum decrease significantly during the off-gas surges. The lowest plenum gas temperature during the $3 X$ off-gas surge was calculated using the melter off-gas dynamics-model. Conservatism was then included in the kinetic calculations of $\mathrm{CO}$ and $\mathrm{H}_{2}$ oxidation by assuming that the plenum gas temperature remained at that minimum throughout the surge period. The reduction in pressure, control air flow during the $3 X$ surge was also calculated using the dynamics model and included in the lower explosive limit (LEL) calculations. It was also checked 
whether or not the plenum gas residence time was longer than 5-6 seconds during the $3 \mathrm{X}$ surge.

If the calculated percent LEL of noncondensable off-gas at a given plenum temperature below $848^{\circ} \mathrm{C}$ was greater than $60 \%$, the film cooler air flow was increased until the percent LEL dropped below $60 \%$. In doing so, Condition \#3 remained satisfied. The maximum jumper I.D. was then recalculated based on the adjusted film cooler air flow rate. It turned out that the minimum plenum thermowell temperature allowable is $765^{\circ} \mathrm{C}$. That is, the calculated percent LEL is $60 \%$ at $765{ }^{\circ} \mathrm{C}$ using the maximum design film cooler air flow. Condition \#8 guarantees that the off-gas remains below $60 \%$ of the composte LEL anywhere in the off-gas system even during the $3 \mathrm{X}$ off-gas surges.

\section{Conditions \#9-12: Melter off-gas equipment design limits}

So far, based on Conditions \#1 through 8, several sets of melter offgas system operating conditions were developed at different plenum temperatures chosen between 765 and $848{ }^{\circ} \mathrm{C}$. It was then checked whether Conditions \#9 through 12 were satisfied by each set of operating conditions. These conditions represent some of the key design limits which must be satisfied to eliminate an adverse impact on continuous, safe operation of the melter off-gas system.

\section{Step 2. Determination of Optimum Operating Conditions}

The DWPF liquid wasto recycle rate was next calculated for each set of operating conditions which satisfies Conditions $\# 1$ through 12 . As shown in Figure 1, the minimum liquid waste recycle rate is found at a plenum temperature of $775{ }^{\circ} \mathrm{C}$ or a gas temperature of $583{ }^{\circ} \mathrm{C}$. At this temperature, the maximum allowable jumper 1.D. is 7.28 inches. The primary film cooler air purge rate was increased to $520 \mathrm{lb} / \mathrm{hr}$ to satisfy Condition $\# 8$ so the resulting air-to-steam mass ratio was 3.5 (Condition *3). Under these conditions, the off-gas temperature at the film cooler exit was $390^{\circ} \mathrm{C}$, and immediately dropped to $317^{\circ} \mathrm{C}$ at the control air entry point.

The primary reasons for choosing the minimum liquid waste recycle rate as the optimization criterion are to, incresse the attainment rate in DWPF and to lower the operating costs in the tank farms. Besides, costly upgrade of process equipment such as chiller and condensers is avoided. 


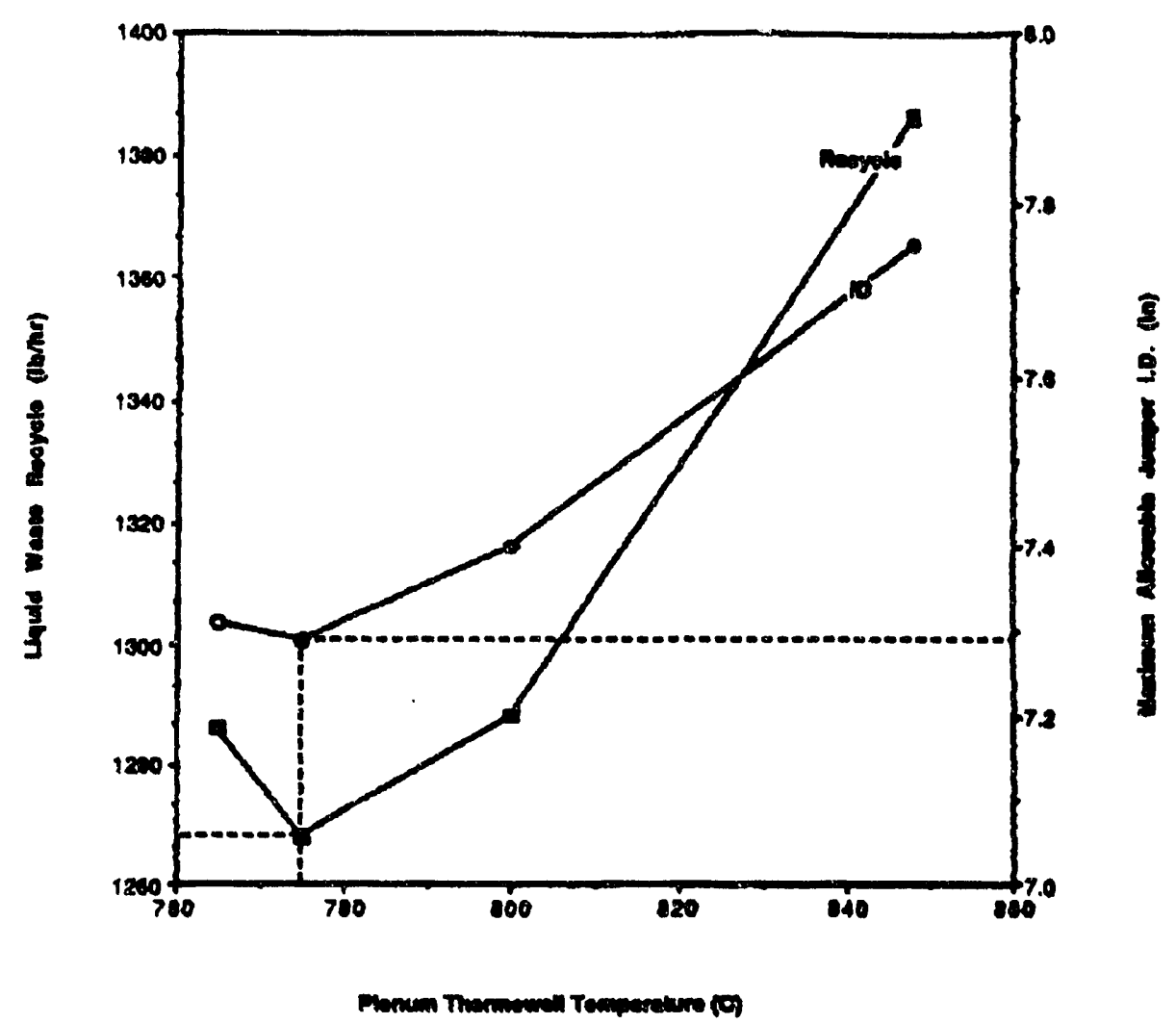

Elenre 1. Optimum Plenum Temperature vo Maximum Jumper I.D.

\section{Step 3. Determination of Minimum Jumper I.D.}

The minimum allowable jumper I.D. is determined by Condition \#13 in Table 1. That is, at 7 times the nominal molter off-gas flow rate, the pressure drop in the new jumper should not be excessively high so that the melter pressure would not rise above $-0.5^{\prime \prime}$ wc. As shown in Figure 2, the results of the dynamic simulation indicated that the melter pressure would peak at just below $-0.5^{n}$ wc during the $7 \mathrm{X}$ offgas surge in a $7.156^{n}$ I.D. jumper . Therefore, the minimum I.D. that is dynamically allowable was set at 7.15 inches. 
7X OIT-GAS DXCURSIOW 775 C IM 7.156" JUPQR

JANUARY 9, 1992
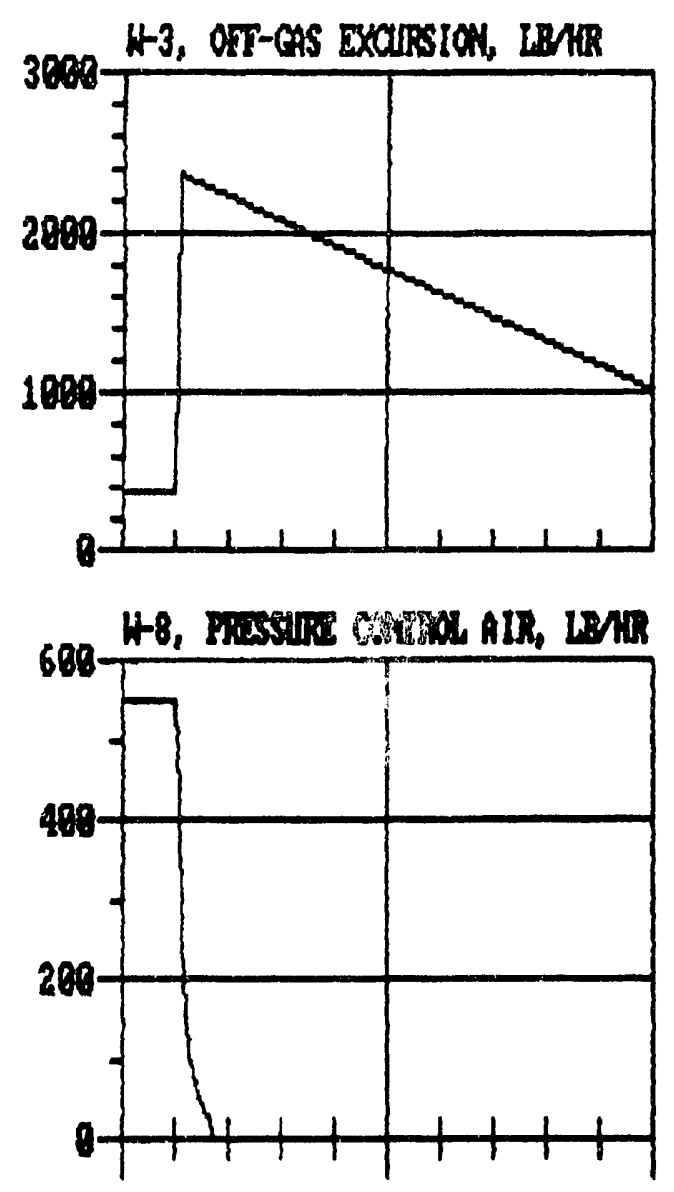

BUN NUMBER: 891
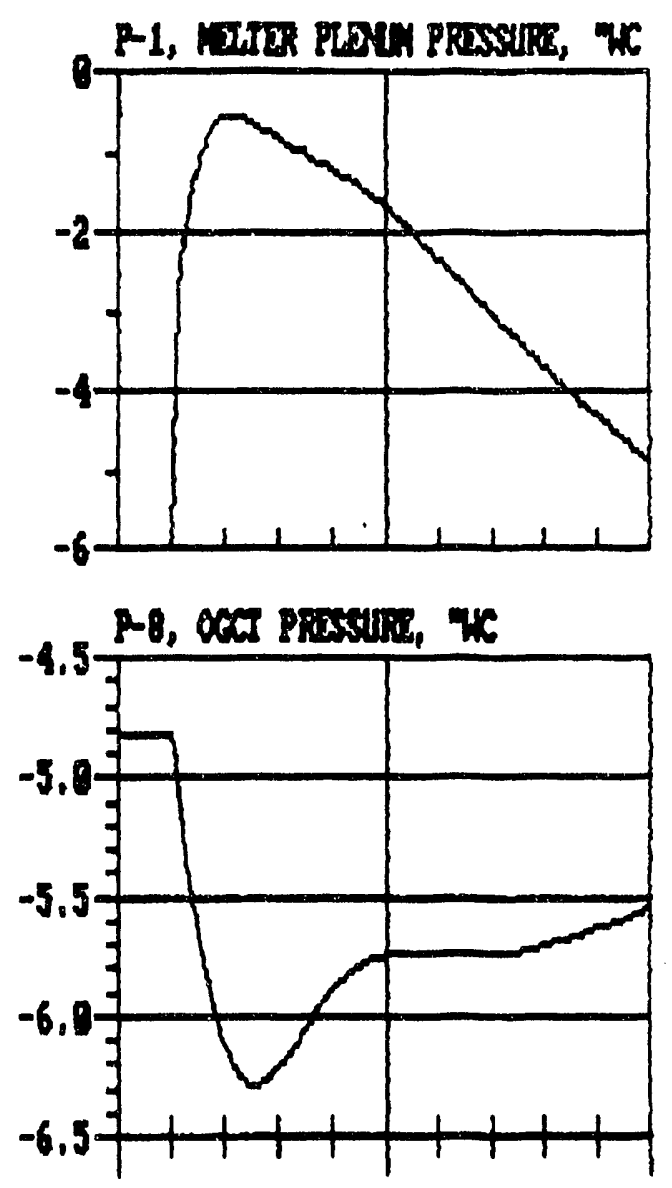

0.0

0.5

1,0

IIre in Mineres

FIGURE 2. Dynamic Simulation Results during $7 X$ Off.Gas Surge in 7.156 inch 1.D. Jumper. 


\section{Conclusions and Recommendations}

In Steps 2 and 3, the upper and lower limits for the new jumper I.D. was determined to be 7.28 and 7.15 inches, respectively. For DWPF design purposes, it is recommended that the new off-gas jumper be built within $7.2 \pm 0.05$ inches.

Note that the optimum I.D. found in this study is less than 1\% larger than the one determined earlier.' However, additional conservatism included in this study requires that the melter be operated at $775{ }^{\circ} \mathrm{C}$, which is $50^{\circ} \mathrm{C}$ higher than the latest flowsheet. 2 The primary film cooler air purge rate should also be increased from 425 to $520 \mathrm{lb} / \mathrm{hr}$. In return, the proposed DWPF jumper design along with the revised operating conditions will ensure that both off-gas line plugging and liquid waste recycle are minimized, while off-gas flammability and dynamic instability during severe off-gas surges are both eliminated.

\section{References}

1. Choi, A: S., "Revised Design and Operating Conditions for the DWPF Melter Off-Gas System (U)," WSRC-TR-91-88, April 22, 1991.

2. Choi, A. S., "Prediction of Melter Off-Gas Explosiveness (U)," WSRC-TR-90-346, to be published. 

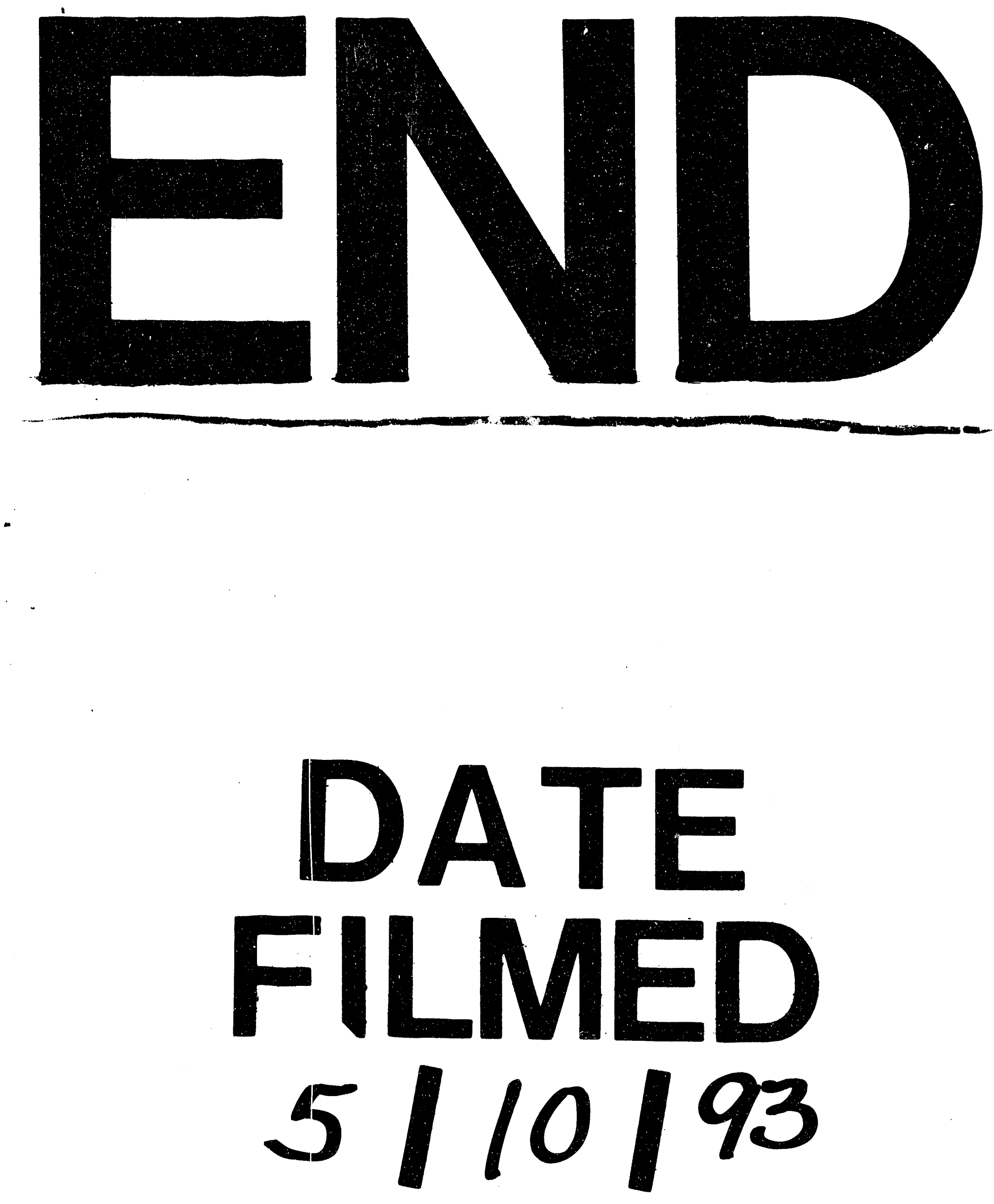